\title{
Potential Microbial Transmission Pathways in Rural Communities using Multiple Alternative Water Sources in Semi-arid Brazil
}

Mario Rodrigues Peres ${ }^{(a)}$, James Ebdon ${ }^{(b)}$, Sarah Purnell ${ }^{(b)}$, Huw Taylor ${ }^{(b)}$

(a) Department of Environmental Engineer, Federal University of Espirito Santo, Goiabeiras, Vitória - ES, Brazil 29075-910.

(b) Environment and Public Health Research and Enterprise Group, Group, Centre for Aquatic Environments, School of Environment and Technology, University of Brighton, Cockcroft Building, Lewes Road, Brighton, BN2 4GJ, United Kingdom

Corresponding Author:

Mario Rodrigues Peres

e-mail: mario.peres@ufes.br

postal address: Departamento de Engenharia Ambiental - UFES, Goiabeiras, Vitoria - ES,

Brazil - 29075-910.

Declarations of interest: none.

\section{Abstract}

Background: Water scarcity combined with high incidences of diarrhoeal disease amongst many rural communities, suggests that the provision of 'safe' water supplies remains a challenge. Subsequent reliance on multi-source water supplies means that microbial transmission pathways may be numerous and complex.

Objectives: This study aimed to identify and elucidate water supply issues and potential microbial transmission pathways at the household level in rural communities in semi-arid Brazil.

Methods: Community and sanitary surveys were applied to 99 households from 10 communities located in four municipalities of Paraiba State, Brazil. Moreover, physicochemical and microbial parameters were investigated throughout the water supply chain.

Results: High levels of faecal indicator organisms (FIO) were detected in water from Water Storage Reservoirs (WSR) and from in-house Drinking Water Storage Containers (DWSC). A decrease in microbial water quality was observed between water stored within WSR's and DWSC's, suggesting potential cross-contamination at the household level. Several common practices were observed among rural residents, such as the use of collection buckets left unprotected outside on the ground, that may have also contributed to the observed decrease. Schematic diagrams illustrating the complex water supply chains and potential microbial transmission pathways were developed to facilitate identification of effective intervention strategies.

Discussion: Decreases in water supply quality were found to be predominantly caused by cross-contamination within the domestic environment due to several factors, including, a lack of awareness and knowledge of 'safe' collection, handling and storage of water, as well as inadequate sanitation services and/or unhygienic practices. In order to improve public health in such communities, more effort should be directed towards education and training of all stakeholders involved in the water supply chain. This would, certainly, support the successful implementation of further 
WASH interventions, consequently increasing the likelihood of achieving reduction of excreta-borne diseases.

\section{Keywords}

Hygiene; sanitation; water-related diseases; water storage; water supply.

\section{Introduction}

An unprecedented rise in demand for food, combined with climate change and growing urbanization, have placed increasing pressures on global water resources and, as a result, water scarcity is becoming a major concern in many parts of the world, especially in semi-arid and arid regions (Bichai and Smeets, 2013). In 2015, the United Nations (UN) reported progress towards the Millennium Development Goals (MDG), highlighting that more than $40 \%$ of the global population already faced water scarcity and projected that this number would increase. Moreover, the UN estimated that 663 million people still did not have access to an improved water source by 2015 (UN, 2015).

When people living in rural and urban areas are considered separately, it becomes clear that progress on sustainable access to safe drinking water and basic sanitation has been uneven and that pronounced disparities still remain between these groups. The WHO/UNICEF (2015) estimates that globally only $4 \%$ of the urban population use some sort of unimproved drinking water source, compared with $16 \%$ living in rural areas. Moreover, only $33 \%$ of rural residents have access to piped water on their premises (UN, 2015). Therefore, the inhabitants of such communities may have no option other than to obtain their domestic water supplies from 'alternative sources', which for the purposes of this research are considered to comprise all water provision other than that which is piped to the consumer's home following centralized treatment using traditional municipal treatment technologies.

As with piped water supplies, alternative water sources may include lakes, rivers, shallow wells, deep boreholes, harvested rainwater, etc., but they are normally not subject to treatment and disinfection and are therefore far more likely to be unfit for human consumption. Bain et al. (2014) observed higher levels of faecal indicator organisms (FIO) from water sources in rural areas in a systematic review of 345 studies. Moreover, drinking water is more likely to become contaminated with pathogens of enteric origin between its source and its point-of-use (POU) (during its collection and transportation, or when it is stored in unhygienic environments) if a sufficient residual chlorine content has not been achieved through municipal drinking water treatment (Waddington et al., 2009; Wright et al., 2004). Consumption of drinking water that has been contaminated by pathogens of faecal origin is widely recognized to be responsible for numerous infectious waterborne diseases (e.g. cholera, typhoid fever etc.). The transmission of excreta-borne diseases can be complex and involve multiple routes (e.g., water, food, fomites, vectors, etc.).

Disparity in 'safe' water and adequate sanitation provision in urban and rural communities is reflected in disease incidence data. In an extensive analysis of household survey data, Günther and Fink (2010) found that children in rural areas 
were more likely to have diarrhoea and their chances of survival were lower than those living in urban areas. Ensuring access to safe water in sufficient quantities for drinking, safe hygiene practice, adequate sanitation, as well as for encouraging personal, domestic and community hygiene is likely to reduce rates of morbidity and mortality within such communities. Moreover, water and sanitation services provide a more cost-effective and locally sustainable solution to minimize the impacts of waterrelated diseases when compared with medical treatment (Montgomery and Elimelech, 2007).

\subsection{The semi-arid region of Brazil}

The semi-arid region of Brazil covers a total area of $969,589 \mathrm{~km}^{2}$ and encloses about $90 \%$ of the North East region of the country, plus the northern region of the state of Minas Gerais (Silva, 2006). It has been estimated that 22.6 million people live in this semi-arid region, of which 38\% (8.6 million) live in rural areas (IBGE, 2010). One of the principal challenges to water supplies within this region results from the limited, but highly variable levels of rainfall (Heikkila et al., 2012). The average annual cumulative precipitation value varies between 250 and $800 \mathrm{~mm}$ (typically distributed over three to five months of the year), whereas average potential evapotranspiration is about $2000 \mathrm{~mm} /$ year (Moura et al., 2007).

The presence of rivers with low discharge rates in this area can be explained by the temporal variability of precipitation and the dominant geology, which is mainly composed of crystalline and sedimentary rocks (Cirilo, 2008). Shallow soils on top of crystalline rocks limit the transfer of water between the river and adjacent soils. Water scarcity affects food supply and is an economic barrier to development, as it impinges on some of the region's main economic generation activities, namely agriculture and livestock rearing. Another barrier to the provision of safe water supply in the semi-arid region of Brazil is related to direct and indirect contamination of water sources associated with the inadequate level of sanitation services and hygiene practices in many parts of this region.

Several national programs to provide 'safe' water to the population of the semi-arid region exist (e.g., Army Operation Tanker, Permanent Program to Fight Drought, Program One Million Cisterns, Program One Land and Two Waters, Cisterns in Schools), but many people still do not have access to sufficient volumes of drinking water of adequate quality. Consequently, the inhabitants of such communities are more likely to consume water of poor quality, increasing the incidence of waterrelated diseases. In order to address these issues, this study aimed to identify and characterise water supply systems and potential water-related microbial transmission pathways for enteric pathogens (from catchment to users), with special consideration to the household domestic environment.

\section{Material and Methods}

This study was based upon a collaboration between the University of Brighton (UoB), UK and Federal University of Campina Grande (UFCG), Brazil which was designed 
to facilitate data collection and laboratory analysis. Due to the considerable size of Paraiba State and the semi-arid Northeast region of Brazil as a whole, only rural communities within a $250 \mathrm{~km}$ radius from UFCG were selected for inclusion in this study due to logistical and time constraints. Paraiba State has a population of approximately 3.77 million inhabitants, of which approximately $25 \% \quad(928,000$ inhabitants) reside in rural areas (IBGE, 2010). Municipalities and rural communities were selected with the support of local authorities, including Health Departments, District health workers) and researchers from UFCG, and were based on ease of access and personal safety concerns.

Site selection was also supported by community leaders, who, in most cases facilitated the application of household surveys and the development of water sampling strategies. In total, ten rural communities located in four (out of 223) municipalities of Paraiba (Table 1) were selected and visited weekly between April and July. All chosen rural communities were within the semi-arid region of Paraiba State, underlain by rocks from the crystalline complex, presenting intermittent (ephemeral) streams and complex water supply systems involving multiple water sources. The four municipalities containing the rural communities visited are illustrated geographically in Figure 1.

Table 1 Population of municipalities, selected rural communities and the number of households per community.

Note: $\mathrm{AB}=$ Assentamento Belmonte; $\mathrm{MG}=$ Mato Grosso; $\mathrm{PF}=$ Papa Fina; $\mathrm{Pe}=$ Pedreiras; $\mathrm{Pi}=$ Picotes; PP = Poço de Pedra; QSA = Quilombola Serra do Abreu; SL = Santa Luzia; Ub = Urubu; Uc = Uruçu.

Figure 1. Location of Campina Grande, Picuí, Nova Palmeira, São João do Cariri, and São Mamede municipalities within Paraíba State.

Source: adapted from IBGE geopackage downloaded from http://geoftp.ibge.gov.br/cartas_e_mapas/ bases_cartograficas_continuas/bcim/versao2016/geopackage/).

* This research was supported by a collaborating university (Federal University of Campina Grande UFCG), which was located in Campina Grande.

\subsection{Surveys}

The minimum number of samples (97) was estimated based on a $10 \%$ margin of error and $95 \%$ confidence level, considering the rural population of Paraiba. Therefore, 99 households were randomly selected in these rural communities, and a cross-sectional survey was performed using a close-end, semi-structured questionnaire. The questionnaire was designed with questions relating to the water supply system, sanitation and hygiene practices and was conducted face-to-face with residents. Moreover, a sanitary inspection was also developed to support the identification of potential sources of contamination based on the researcher's observation. This was achieved through the use of a form containing five questions 
including issues relating to rainwater harvesting systems (e.g., presence or absence of 'first flush'), water storage cisterns and hygiene practice.

A brief explanation of the project and the reasons for the survey were provided to all respondents within each household, who were also informed how the data would be used. Participation was voluntary, and respondents could withdraw from it at any point in time. Questionnaires were only applied to households that agreed with the research terms included in the consent form. All activities were conducted in accordance with University of Brighton ethical requirements (University of Brighton, 2016).

\subsection{Water Monitoring Program}

Monitoring was conducted during the 2016 rainy season (April to July) so as to coincide with the period when rainfall and water supplies were most abundant and when households are least reluctant to hand over valuable water samples for water quality analysis. Furthermore, certain water-related transmission pathways may be more easily identified during the rainy season when contamination of groundwater, or stored water supplies with surface inputs is most likely to occur.

Single grab water samples were taken from each storage device, including Water Storage Reservoirs (WSR) and in-house Drinking Water Storage Containers (DWSC), present within the 99 households visited during the monitoring program ( $\mathrm{n}$ $=262$ ). The number of water samples was considerably higher than the number of households surveyed because most of the houses presented multiple sources and/or water storage devices. Each household was visited on one occasion during the study. Water samples from alternative water sources (e.g. tankered water and desalinated water) were also collected for comparison. Thermo-containers, partially filled with ice, were used to keep samples refrigerated during transportation to the laboratory. All microbiological samples were processed within 12 hours of collection.

Water samples were collected outside each dwelling from the midpoint of the WSR, at $10-15 \mathrm{~cm}$ below the water surface through direct sampling into one litre sterile polypropylene containers (Thermo), or using buckets tied to a rope (as used by residents) to decant into the sampling containers. Furthermore, at sites which had functioning hand-pumps, samples were collected directly from the outlet. Sodium thiosulfate $(1.0 \mathrm{~mL}$ at $1 \%)$ was added to sample containers $(500 \mathrm{~mL})$ to neutralize any residual free chlorine potentially present. Samples collected from surface waters (including those from ponds and lakes) were obtained approximately one metre from the bank, at $10-15 \mathrm{~cm}$ below the surface, while groundwater samples were collected from the pump outlets prior to entering water reservoirs.

All water samples were analysed for physicochemical parameters in the field at the time of sampling using portable equipment. Microbiological parameters were analysed at LABDES laboratory, located at the Federal University of Campina Grande (UFCG). 


\subsection{Physicochemical Analysis}

Temperature, $\mathrm{pH}$ and electrical conductivity were tested using a multiparameter Aquaread meter (model AP-2000) (AQUAREAD, Broadstairs, UK). Turbidity was measured in Nephelometric Turbidity Unity (NTU) with a portable turbidimeter $(\mathrm{HACH} 2100 \mathrm{Q}$, Loveland, USA). A free-chlorine water test (SenSafe $\circledast$, Rock Hill, USA) was performed when the survey respondent claimed to use some form of chlorine-based product for disinfection.

\subsection{Microbiological Analysis}

All faecal indicator organisms (FIO), including E. coli, intestinal enterococci (IE) and somatic coliphages, were presumptively enumerated by culture-based methods in accordance to standardized methods. Bacterial analyses were performed using membrane filtration technique using $0.45 \mu \mathrm{m}$ cellulose nitrate membranes (Sartorius, Goettingen, Germany). E. coli were analysed according to the standard method BSEN-ISO 9308-1 (BSI, 2000a). However, for the detection of E. coli, tryptone bile xglucuronide (TBX) (CM0945), which is a specific chromogenic medium, was used. IE were enumerated in accordance with the standard method BS-EN-ISO 7899-2 (BSI, 2000b) while somatic coliphages were enumerated according to the standard method BS-EN-ISO 10705-2 (BSI, 2001). Quality assurance tests were always performed when microbial analyses were performed, this included positive controls (confirmation step using pre-prepared reference materials) and negative controls (conducted using distilled $\mathrm{H}_{2} \mathrm{O}$ ).

\subsection{Statistical Analysis}

All statistical analyses presented in this document were performed with Minitab (version 17). A macro to run Kruskall-Wallis multiple comparisons was downloaded from the Minitab support webpage, allowing for multiple comparisons among three or more groups using the Dunn's Bonferroni p-value adjustment to control the familywise error rate. The family-wise error rate ( $\alpha$ ) was setup to a significance level of 0.05 and p-value adjusted accordingly to the number of groups evaluated. Finally, in order to investigate correlations between levels of physicochemical and microbial parameters and outcomes from the surveys, the Spearman's rho test (nonparametric version of the Pearson correlation) was used.

\section{Results}

It is important to note that from here on the term 'water sources' refers to the type of water delivered to (and stored within) the household water storage reservoir (WSR) (e.g., tankered water, desalinated water or harvested rainwater), rather than its 'original' source (e.g., groundwater, rainwater or surface water), which is referred to as 'original source'. 


\subsection{Household and sanitary surveys}

\subsubsection{Water supply}

In total, ten water sources were identified in the rural communities studied (Table 2). The most common source used by these rural communities was harvested roof runoff rainwater, followed by water provided by tankers (army operation and municipal government programs). Although, ninety-two per cent of households reported having sufficient water for basic domestic activities (e.g., drinking and cooking) throughout the year, most households (87\%) used two or three alternative sources and $79 \%$ of respondents reported having at least two WSR's. Figure 2 shows the number of households within each community that reportedly used one or more water sources. About half of WSR's evaluated stored a single water source $(55 \%)$, whereas $45 \%$ of them contained a mix of two or more water sources.

Table 1. Number and type of water sources used by rural communities.

Note: AB, Assentamento Belmonte; MG, Mato Grosso; PF, Papa Fina; Pe, Pedreiras; Pi, Picotes; PP, Poço de Pedra; QSA, Quilombola Serra do Abreu; SL, Santa Luzia; Ub, Urubu; Uc, Uruçu; HRRW, harvested roof run-off rainwater; CT, community tubewell; DW, desalinated water; HPT, household private tubewell; AOT, army operated tanker; MGOT, municipal government operated tanker; HCSRW, harvested cemented surface run-off rainwater; HGSRW, harvested ground surface run-off rainwater; DP, dew ponds; POT, privately operated tanker.

Drinking water was (reportedly) collected most frequently from outside WSR's (e.g., cistern, tanks, etc.), using a bucket attached to a rope $(79 \%)$ and hand pump $(14 \%)$. When residents were asked about the cleaning frequency of their WSR, $84 \%$ reported that they cleaned it whenever the water supply ran out, $5 \%$ cleaned it at least once a year and $11 \%$ reported that they had never cleaned it. Although a high proportion of households reported cleaning their WSR, a lower number reported using chlorine-based products $(37 \%)$ to perform this task, with most using only water for cleaning $(52 \%)$.

Most householders reported using only one water source for drinking (68\%), whilst $32 \%$ reported using a second source when the first option was not available. Most households used harvested roof run-off rainwater (72 out of 99), followed by tankered water (25) and desalinated water (24) for this purpose. The majority of households reported using commercial plastic containers $(33 \%)$ to store their drinking water, followed by clay pots $(30 \%)$ and ceramic candle filters/clay pots $(21 \%)$. However, a smaller proportion of households reported keeping their drinking water within the property in buckets, which were normally covered with a piece of cloth.

Figure 2. Number of households that reported to use one or more water sources by community.

Note: AB, Assentamento Belmonte; MG, Mato Grosso; Pe, Pedreiras; PF, Papa Fina; Pi, Picotes; PP, Poço de Pedra; QSA, Quilombola Serra do Abreu; SL, Santa Luzia; Ub, Urubu; Uc, Uruçu. 
About $87 \%$ of households reported cleaning their DWSC before 'new' water was added to the container and $10 \%$ reported cleaning it weekly. However, only $32 \%$ of respondents reported that they cleaned their DWSC with a chlorine-based product, whilst $23 \%$ reported cleaning it out with water and soap and most $(45 \%)$ reported using only water. Furthermore, about half of households reported practicing some form of treatment $(29 \%$ chlorination, $15 \%$ ceramic filtration, and $7 \%$ chlorination + ceramic filtration) before consuming the water, while the other half were observed to be drinking water with no prior treatment at all. Finally, with regards to the decanting of drinking water from in-house DWSC's, the majority of households had a DWSC with a tap fitted $(50 \%)$, whereas about $42 \%$ used cups/glasses to scoop up water from the DWSC and $8 \%$ poured directly from the DWSC into a cup or glass.

\subsubsection{Sanitation and hygiene}

A high number of households were observed to possess a shower head for showering $(42 \%)$, whilst the remaining $58 \%$ used a cup to pour water over the body. The average volume of water used for showering/bathing was reported to be approximately 14 litres per person per shower. Most respondents (63\%) agreed that shower wastewater was a potentially valuable resource, which was therefore used to irrigate domestic plants/crops. The majority of rural communities studied $(95 \%)$ did not have any formal solid waste collection, with $97 \%$ resorting to burning their waste and $3 \%$ to burying it on site. Finally, about $89 \%$ of households possessed a pourflush toilet system, which most commonly (97\%) discharged into soakaways located in the backyard of the dwelling, whereas the remainder discharged in the backyard.

\subsubsection{Training related to water, sanitation and hygiene}

The proportion of households that reported having received training (e.g., as part of Brazilian government programs) with regards to safe storage, transportation of drinking water (or maintenance and cleaning of water storage facilities) was very low. Eleven out of 72 households from six communities claimed not to remember whether they had received any such training, whilst more than half of the remaining 61 households reported not having received this training. This suggests that lack of adequate household or community-level health and safety training (including followup training) may constitute a significant problem in the study area. Householders were also asked whether they had received any training or guidance with regard to the inspection, maintenance and emptying of 'septic tanks', or to 'best practice' in terms of personal and domestic hygiene. All households reported not to have received any such guidance.

\subsubsection{Sanitary survey}

The sanitary survey revealed that most of rainwater harvesting system (RWHS) did not possess a first-flush device (94\%). Moreover, only $7 \%$ of households presented fencing to protect water storage reservoirs (WSR), which was not a common practice among the residents in these communities. Finally, the presence of litter and/or 
faeces around the house did not seem to be a major issue in these communities as these materials were rarely observed.

\subsection{Water Monitoring Program}

It is important to mention that somatic coliphages were detected in only $19 \%$ and $20 \%$ of samples from WSR and DWSC, respectively (detection limit of 50 PFU per $100 \mathrm{~mL}$ ). As it would be necessary to replace 'undetected' results (a major part of the dataset) with the limit of detection, it was concluded that this could lead to misinterpretation of the results. Therefore, the results with regards to somatic coliphages were discarded and not considered in the analysis presented in this section.

\subsubsection{Quality of source waters}

E. coli and enterococcus were detected at a maximum concentration of $18 \mathrm{CFU} / 100$ $\mathrm{mL}$ in water samples collected from community (not household) desalinated water storage reservoirs, groundwater, surface water and army-operated tankers (including samples collected $20 \mathrm{~min}$ after the addition of chlorine tablets and at the moment at which water was being delivered).

Staff from the tanker operation were asked about the residual free chlorine and FIO monitoring of the delivered water. They reported that water analysis was not performed at the location at which the tankers were filled. Although the addition of chlorine tablets was observed during the filling of tankers, only one sample (collected 20 minutes after chlorine addition) presented a residual free chlorine of $0.1 \mathrm{mg} / \mathrm{L}$ (limit of detection $=0.05 \mathrm{mg} / \mathrm{L}$ ). Statistical tools to investigate the significance of differences in water quality among these sources could not be performed due to limited observations.

\subsubsection{Quality of water within household water storage reservoirs}

The results of physicochemical and microbiological analyses of water, including all household WSR from all rural communities are presented in Table 3. All parameters analysed demonstrated wide ranges, which reflects the complexity of multi-source water supply systems. It is important to mention that in the following analysis, 'mixed waters' refers to samples from WSR containing water from two or more sources, with the condition that none of the sources had a volumetric percentage contribution of $80 \%$ or higher. Moreover, for the purpose of this analysis, all harvested rainwater samples were considered, regardless of the harvesting area (roof, cemented and not-cemented ground), whereas the results of source water monitoring, including privately operated, municipal government operated and the army operated tankers, were grouped as 'tankered water'. Figure 3 presents the results of the analysis for $\mathrm{pH}$, temperature, electrical conductivity and turbidity.

Table 2. Descriptive statistics for physicochemical and microbiological parameters for water from water storage reservoirs. 
Note: $n$, number of observations; NTU, nephelometric turbidity units; $\mu \mathrm{S} / \mathrm{cm}$, microsiemens per centimeter; IE, intestinal enterococci; CFU, colony forming units.

Figure 3. Boxplots to demonstrate the median and IQR for $\mathrm{pH}$ level, temperature, electrical conductivity and turbidity for water samples from water storage reservoirs.

Note: $\mu \mathrm{S} / \mathrm{cm}$, microsiemens per centimeter; NTU, nephelometric turbidity units; GW, groundwater; HRW, harvested rainwater; MW, mixed water; TW, tankered water.

* Outliers were removed from the turbidity boxplot to facilitate the visualization of median and IQR. Only two samples of mixed waters, harvested rainwater and tankered water presented measurements of turbidity higher than 100 NTU.

Although pure rainwater normally presents a slightly acidic $\mathrm{pH}$, varying from 4.5 to 5.6 (Liljestrand, 1985), the $\mathrm{pH}$ for harvested rainwater (Median $=8.55(8.24-8.72), \mathrm{n}$ $=72$ ) was observed to be significantly higher than groundwater (Median $=7.40$ (5.50-7.82), $\mathrm{n}=27$ ) and water delivered by tankers (Median = 8.19 (7.91-8.45), $\mathrm{n}=$ 34) (adjusted p-value < 0.008). Groundwater presented significantly higher temperature $\left(\right.$ Median $\left.=26.9(26.1-30.4){ }^{\circ} \mathrm{C}, \mathrm{n}=27\right)$ and electrical conductivity (Median $=2701(783-4293) \mu \mathrm{S} / \mathrm{cm}, \mathrm{n}=25)$ compared with all other alternative sources (adjusted p-value $<0.008$ ), whereas significantly lower electrical conductivity was observed for harvested rainwater (Median = 145.5 (104-248) $\mu \mathrm{S} / \mathrm{cm}, \mathrm{n}=64$ ) (adjusted $\mathrm{p}$-value $<0.008$ ). In terms of turbidity, relatively low levels were observed for most samples, but harvested rainwater (Median $=0.97$ (0.612.28) NTU, $n=76$ ) presented significantly lower levels compared with tankered water (Median $=1.6(1.2-4.1)$ NTU, $\mathrm{n}=35$ ) (adjusted $\mathrm{p}$-value < 0.008). It is important to bear in mind that these results do not reflect the water quality at its original source but rather its quality once delivered and stored within different external WSRs.

With regard to the microbiological analysis, E. coli were detected in $86 \%$ and intestinal enterococci (IE) in $93 \%$ of water samples from WSRs. Considering all WSRs, the median concentration of IE was observed to be significantly higher than that of $E$. coli ( $p$-value < 0.05). Figure 4 presents boxplots illustrating the median concentration and Inter Quartile Range (IQR) of $E$. coli and IE with regard to the various source waters and different WSRs. There was no significant difference in median $E$. coli and IE concentrations with respect to the various alternative water sources (i.e., groundwater, harvested rainwater, mixed waters and tankered water), stored in different WSR at significance levels of 0.008 and 0.008 , respectively.

Figure 4. Boxplot showing the median and IQR for the concentration of E. coli and IE $(\log 10$ CFU/100 $\mathrm{mL}$ ) in water collected from water storage systems with regard to various alternative source (left) and different water storage systems (right).

Note: GW, groundwater; HRW, harvested rainwater; MW, mixed water; TW, tankered water; IE, intestinal enterococci; CFU, colony-forming units.

Interestingly, no significant difference in the median concentration of either $E$. coli and IE with respect to the main procedures used to collect water from WSR was observed in the study (buckets tied to a rope and hand pumps) ( $p$-value $<0.05$ ). 
Moreover, no significant difference was observed in the median concentration of $E$. coli and IE among the households that reported cleaning their WSR at least once a year $(85 \%)$, the participants that reported always cleaning their WSR when it became empty $(5 \%)$, and the ones that reported never to have cleaned it $(10 \%)$ (adjusted p-value $<0.0167$ ). No correlation was observed between the information gathered through the sanitary survey against water quality monitoring data.

\subsubsection{Quality of water from in-house drinking water storage containers}

Temperature, $\mathrm{pH}$ and electrical conductivity were not measured in DWSC because of sample volume constraints. Moreover, groundwater sources were excluded of this analysis because of the limited number of drinking water samples (two) originating from groundwater sources. Turbidity, free chlorine and FIO results from the various drinking water samples are presented in Table 4.

Table 3. Descriptive statistics for turbidity, free chlorine, E. coli and IE, considering all water samples collected from household in-house drinking water storage containers.

Note: $n$, number of observations; NTU, nephelometric turbidity units; IE, intestinal enterococci; CFU, colony-forming units.

As for WSR, the concentration of IE was significantly higher than that of E. coli ( $p$ value $<0.05)$ in drinking water from in-house DWSCs. It is relevant to mention that although 35 out of 99 households reported using chlorine tablets to disinfect their drinking water, residual free chlorine was detected in only one sample at a level of $1.2 \mathrm{mg} / \mathrm{L}$ (limit of detection $=0.05 \mathrm{mg} / \mathrm{L}$ ).

With the exception for mixed water, harvested rainwater and tankered water were grouped in the same manner previously explained in section 3.2.2. Significantly higher turbidity levels were observed in DWSCs containing water originating from tankers (Median $=1.42(0.98-2.91)$ NTU, $n=13)$ compared with those containing harvested rainwater (Median $=0.69(0.36-1.12)$ NTU, $n=51$ ) and desalinated water (Median $=0.48(0.29-0.95)$ NTU, $n=17)$ (adjusted $p$-value $<0.0167)$. With respect to the microbial quality of drinking water (Figure 5), no differences in the concentration of $E$. coli and IE were detected with respect to the various water sources stored in DWSCs (significance level of 0.0167).

Interestingly, when the different approaches used to collect drinking water from DWSCs were evaluated, the median concentration of $E$. coli and IE was observed to be significantly higher for households that used cup/glasses to scoop up water from the DWSC (Median = $15(2-40)$ CFU/100 mL, $\mathrm{n}=38$ and Median = $112(42-500)$ CFU/100 $\mathrm{mL}, \mathrm{n}=37$, respectively) compared to DWSCs with taps (Median $=1(1-7)$ CFU/100 $\mathrm{mL}$ and Median $=17(1-125) \mathrm{CFU} / 100 \mathrm{~mL}, \mathrm{n}=42$, respectively) (adjusted p-value < 0.0167) (Figure 6).

Figure 5. Boxplots to demonstrate the median and IQR for the concentration of E. coli and IE (log10 CFU/100 mL) for drinking water samples collected from in-house drinking water storage containers, with regard to different water sources. 
Note: DW, desalinated water; HRW, harvested rainwater; TW, tankered water; IE, intestinal enterococci; CFU, colony-forming units.

Figure 6. Boxplots showing the median and IQR for the concentration of E. coli and IE $(\log 10 \mathrm{CFU} / 100 \mathrm{~mL})$ for water samples collected from DWSC considering different procedures, performed by households, to collect drinking.

Note: IE, intestinal enterococci; CFU, colony-forming units.

In terms of water treatment, drinking water treated by ceramic candle filters (Median $=1(1-1.8) \mathrm{CFU} / 100 \mathrm{~mL}, \mathrm{n}=20)$ showed a significantly lower median concentration of $E$. coli compared with water reported to be treated with chlorine and non-treated water (adjusted p-value < 0.0167). Moreover, the median concentration of IE was also significantly lower in water from ceramic candle filters (Median $=4.5(1-52)$ CFU/100 mL, $\mathrm{n}=20$ ) compared with non-treated water (adjusted p-value $<0.0167$ ) (Figure 7). Frequency of cleaning and procedures used to clean the DWSC did not appear to contribute to any significant difference in the median concentration of $E$. coli and IE. A moderate correlation between $E$. coli and IE (Spearman Rho $=0.521$, p-value $=0.000$ ) and a weaker correlation between IE and turbidity (Spearman Rho $=0.254, p$-value $=0.018)$ was observed among water samples from DWSC.

Figure 7. Boxplots showing the median and IQR for the concentration of $E$. coli and IE $(\log 10 \mathrm{CFU} / 100 \mathrm{~mL})$ for water samples stored at DWSC, with respect to different water treatment (or no treatment) performed by households.

Note: IE, intestinal enterococci; CFU, colony-forming units.

Independently of the treatment used by the households, IE always presented at higher concentrations in drinking water samples compared with $E$. coli. The median concentration of $E$. coli and IE in drinking water samples from households that reported treating water with chlorine (Median $=4(1-29) \mathrm{CFU} / 100 \mathrm{~mL}, \mathrm{n}=29$ and Median $=65$ (17-205) $\mathrm{CFU} / 100 \mathrm{~mL}, \mathrm{n}=28$, respectively) did not differ from those that reported not treating the water prior to consumption (Median $=10(1-38)$ $\mathrm{CFU} / 100 \mathrm{~mL}$ and Median $=118(24-650) \mathrm{CFU} / 100 \mathrm{~mL}, \mathrm{n}=39$, respectively) (adjusted p-value < 0.0167) (Figure 7).

\section{Discussion}

The collection of detailed household survey data was challenging, especially when participants were requested to report on the use of soap for showering and dishwashing, or on the use of chlorine, for example. Indeed, self-reporting of questions related to socially desirable activities, such as hand washing has been criticized as unreliable (Judah et al., 2009). To support the collection of more representative information on this issue, observation by the researcher of the interior of the house would have been desirable. However, such access was seldom granted by residents during this study. Therefore, further research is needed to more effectively capture and measure personal and domestic hygiene practices in domestic settings. 
The information collected through the sanitary inspection was much easier to obtain because it did not depend on resident's responses but only on the researcher's observation. The sanitary inspection allowed the identification of potential issues related to the installation and maintenance of rainwater harvesting systems such as the absence of fences and 'first flush' devices to protect water quality observed in most of systems visited. Despite such challenges, the information gathered during household surveying and sanitary inspection supported a better understanding of residents' practices regarding water handling, storage and treatment, sanitation, and domestic \& personal hygiene. The water monitoring program allowed the determination of faecal contamination at various points along the water supply chain.

In order to clarify the observed higher temperature for groundwater, a crosstabulation of water sources and WSR (data not shown) revealed that the higher temperature was very likely caused by the material of the WSR holding groundwater (mostly fiberglass) combined with the fact that they were fully exposed to sunlight. Moreover, it appears that one of the factors influencing the high $\mathrm{pH}$ observed in harvested rainwater sources was the material used to build the cisterns (cement plates), which has been previously observed to cause an increase in $\mathrm{pH}$ (Xavier, 2010).

Overall, faecal indicator organisms (FIO) were detected in $95 \%$ of (297 of 312) water samples processed during this study, with a greater prevalence of IE. High levels of FIO from water sources in rural areas has already been observed by Bain et al. (2014) during a systematic review of 345 studies. In total, about $80 \%$ of samples from in-house drinking water storage containers did not comply with the Brazilian drinking water standards (MS, 2011) (absence of $E$. coli in $100 \mathrm{~mL}$ ). A definitive conclusion about the significantly higher level of IE (compared to $E$. coli) could not be drawn from the evidence of this study. However, one possibility is that IE are capable of prolonged survival in freshwater and sediments as observed in previous research (e.g., Glass-Haller, 2010; Guan and Holley, 2003). In fact, E. coli/IE ratios were observed to decline from WSR to in-house DWSC, which further suggests that IE exhibit preferential survival compared to $E$. coli in water under the climatic conditions of the study.

Furthermore, previous research has observed the growth of IE (Byappanahalli et al., 2012; Desmarais et al., 2002) and E. coli (Byappanahalli and Fujioka, 2004, Djaouda et al., 2013) in environmental matrices (including soil and water). Therefore, the observed levels of FIO in WSRs could potentially be a result of the microbial regrowth, although this assumption seems less probable because of the lower concentration of FIO observed in harvested rainwater stored in DWSC compared with WSRs, suggesting that if there were any microbial regrowth within DWSC, its magnitude was lower compared to the decay rate.

The findings of this study suggest that this increase was predominantly due to considerable microbial cross-contamination, which is consistent with the findings of Pinfold (1990), who also noticed that the quality of domestic stored water was closely related to peri-domestic, water-related activities and not to its quality at source. The main potential cross-contamination likely to have contributed to the observed 
increase were related to the lack of knowledge regarding 'safe' handling and storage of drinking water, as well as the inadequate hygiene practices within the household environment. Moreover, the absence of 'first-flush' devices and fencing to protect water within WSR, or poor care and handling of water collection containers (e.g., contact with the soil surface) may also have contributed contamination, to varying extents. Furthermore, health professionals supporting rural communities were observed to lack sufficient knowledge and adequate training to effectively support the residents of these communities.

Interestingly, the levels of somatic coliphage were in marked contrast with the findings of several previous published studies which suggested that they tend to survive longer in soil and water compared to E. coli in such matrices (Jofre et al., 2016; Mocé-Llivina et al., 2005). In this study, somatic coliphages were rarely detected in water samples containing $E$. coli. It has been suggested that somatic coliphages are unlikely to multiply to any great extent in the natural environment (Jonczyk et al., 2011), and therefore, survival and regrowth of indicator bacteria in water and soil within semi-arid environments needs to be further investigated.

Brazilian government programs to support rural communities in the semi-arid study area were shown to be successfully supplying a satisfactory quantity of water to households, even during drought periods. However, a considerable number of residents did not know the origin of the water supplied by the army operation program, which they believed it to be safe because it was what the householder's referred to as 'água doce' ('sweet water'). This reference to 'sweet water' originates from before the implementation of the government programs, at a time when most residents consumed brackish groundwater, which was salty to taste. Therefore, any water which was not salty was assumed to be 'good quality' regardless of its microbiological quality.

Our findings strongly indicate that drinking water delivered by the army operation were highly vulnerable to faecal contamination caused by the inadequate disinfection and abstraction of unprotected surface waters. Low levels of free chlorine $(<0.1$ $\mathrm{mg} / \mathrm{L}, 20 \mathrm{~min}$ after the addition of chlorine tablets) were observed in this study, which was far below the Brazilian drinking water standards (minimum residual level of 0.5 $\mathrm{mg} / \mathrm{L}$ ) (MS, 2011). Although many variables such as shape of tank, type of mixture, contact time can affect the distribution of chlorine within the tank, chlorine was observed to be added when tankers were being filled up using high-flow pumps, which can promote a fast dissolution of chlorine tablets and ensure complete mixing of water. Therefore, lack of knowledge and experience among staff involved with the chlorine dosing was very likely the main factor affecting the low levels of free chlorine observed in such tankered water.

A few residents reported that the government program discouraged the installation of electrical pumps (to divert water to a tap within the house), despite it being wellrecognized that piped water to premises can maximize health gains, putting it on the highest rung of the JMP drinking water service ladder (Shields et al., 2015). A staff member of the army operation explained that promotion of such electric pumps could lead to an increase in the volume of water consumed per household. 
With respect to drinking water treatment, despite chlorine being a 'cornerstone' of most municipal water disinfection systems, the level of its acceptability as a household-level treatment option has been observed to be very low in several studies (Firth et al., 2010; Makutsa et al., 2001). In this research, some respondents reported not using chlorine because of taste and odour issues, whereas others did not demonstrate an understanding of the concept of waterborne disease transmission through the presence of microbial pathogens in potable water. However, a considerable number of households reported using chorine tablets, although chlorine was rarely detected (just once). This discrepancy may have been caused by the non-application of chlorine tablets, or inadequate dosage. It is relevant to mention that some participating householders were concerned about a perceived loss of benefits from government programs, and therefore, their answers to questions around the use of chlorine and frequency of cleaning may be an overestimate compared to what was done in reality.

Although some authors observed that POU treatment seems rarely if ever to be used as envisaged (McLaughlin et al., 2009), in this study, ceramic candle filters were observed to be particularly effective at removing FIO (Figure 7). This suggests that microbial quality of drinking water might be improved using these filters prior to consumption, which is consistent with the findings from previous research (PerezVidal et al., 2016). Furthermore, this simple device appears to have high social acceptability in the communities studied.

The rural households visited in this study could be defined as having a 'basic level' service, according to a recently revised ladder for drinking water service level (WHO/UNICEF, 2017), which corresponds to the use of 'improved' drinking water sources collected at a point no more than 30 minutes (roundtrip) from the home. Although, residents of the study communities were consuming water from 'improved' sources, the use of a 'basic' drinking water service was not associated with any improvement in the quality of consumed drinking water, with regards to $E$. coli and IE as water quality appeared to deteriorate within WSR and DWSC in the domestic environment (Figure 8).

Figure 8. Boxplot to show the median and IQR for the concentration of $E$. coli and IE ( $\log 10$ CFU/100 mL), with respect to different water reservoirs for desalinated water (left), and tankered water (right) (army operation program).

Note: $\mathrm{CFU}=$ colony-forming units; WS = water source; DWSC = in-house drinking water storage containers; WSR $=$ water storage reservoirs; IE $=$ intestinal enterococci.

Combining the information gathered during field work with the water monitoring outcomes, it was possible to construct schematic diagrams depicting the complex water supply systems (Figure 9) and microbial transmission pathways present within the domestic environment (Figure 10) of the rural communities visited. The complexity of the water supply system and the number of potential microbial transmission pathways present within the domestic setting, suggest that the provision of 'safe' water and the implementation of sanitation and hygiene interventions will need to be carefully designed and implemented. 
Figure 9. Schematic representation of the water supply system in rural communities visited in the semi-arid of Brazil.

Notes:

* Water sources at its origin: groundwater, rainwater and surface water

* Water sources delivered to water storage reservoirs (WSR): army operation tankers, cemented area run-off, ground run-off, municipal tankers, private tankers and roof run-off.

* WSC and in-house drinking water storage containers (DWSC): desalinated water reservoir, dew pond, DWSC, cistern P1MC/Private, cistern P1+2, Open water tank and water tank (cement/fibreglass).

* Water treatment techniques: ceramic candle filters and chlorine tablets.

* Water uses: drinking water, food preparation/cooking, general uses, irrigation and livestock.

Most of microbial transmission pathways identified in this research were related to water. For instance, in this study, a few residents were observed to handle glasses inappropriately (e.g., fingering the inside of the glass) prior to filling up with drinking water, showing that even the most appropriate intervention to provide 'safe' water at the DWSC would probably not support a significant decline in the incidence of diarrheal diseases as expected. However, a few microbial transmission pathways (not directly related to drinking water such as hand-to-mouth, hand-food-mouth and fomite-food-mouth), were also identified as they appeared to be very relevant in the studied communities and have been previously observed by some researchers (e.g., Briceno and Yusuf, 2012; de Wit et al., 1979, Humphrey, et al., 2001; Kagan et al., 2002; Scott and Bloomfield, 1990).

Figure 1. Schematic representation of the microbial transmission routes within the domestic environment in rural communities visited in the semi-arid of Brazil.

Notes:

* WSR, water storage reservoirs; TC, transport container; DWSC, in-house drinking water storage container; and DC, drinking container.

* Contamination sources: animal and human feces.

* Intermediate cross-contamination critical points: dishes, drying clothes, flies, fomites, food, hands, hand-washing container, land surface and soakaways, washing-up container.

* Water cross-contamination critical points: DC (e.g. glass), DWSC, TC, WSR.

Ensuring access to safe potable water for human consumption and other domestic activities (e.g., dishwashing and hand washing) is fundamental to the overall improvement in public health. It is equally important to ensure that adequate education and training are provided to all stakeholders involved in the provision of safe drinking water, particularly those social and health workers responsible for communicating advice to rural populations. Despite of the challenges in implementing behavioural change interventions (Curtis et al., 2001; Makutsa et al., 2001; Pinfold, 1990), behavioural changes, including promotion of hand-washing, sanitation, and safe food and water handling are crucial in order to ensure sustainable safe water systems that maximize human health benefits (CDC, 2014). 
Training on domestic and personal hygiene should be developed in an appropriate manner, allowing an extended period for behavioural changes to be agreed and taken up by residents. Introducing domestic and personal hygiene education in schools has previously been identified to be a highly effective way of ensuring longterm behavioural change (Dreibelbis et al., 2014; O'Reilly et al., 2008) and should therefore be vigorously promoted in these rural communities. Research has shown that children tend to be more receptive to such new knowledge compared with adults (Gopnik et al., 2015), and it has been shown that when handwashing becomes part of the daily routine in childhood it persists in adulthood (Curtis et al., 2009; Gopnik et al., 2015).

The potential microbial transmission pathways identified in this research (Figure 10) support planning and management of water supplies in rural communities of semiarid regions, based on the fact that many of the issues encountered in the rural communities of semi-arid Brazil are likely to be applicable to others elsewhere. It is expected that the findings of this research can support the development of more resilient and sustainable water safety plans and interventions in water, sanitation and hygiene (WASH) to reduce the incidence of diarrhoea among population of rural communities in semi-arid regions, ultimately promoting health gains and improving quality of life for those residents.

\section{Conclusion}

- The water supply in the rural communities of semi-arid Brazil were extremely complex and presented numerous microbial transmission pathways (including faeces-hands-mouth, faeces-water-mouth, faeces-food-mouth, faeces-handsfomites-mouth, and others presented in Figure 10) identified within the domestic environment at the household level.

- Although residents reported that the volume of water supplied to rural households within the study area has increased following the introduction of Brazilian government programmes, there is a clear need to focus on improving its quality in order to further reduce diarrhoeal disease within such communities.

- Relatively high levels of microbial contamination (E. coli $=22$ (4-108) CFU/100 $\mathrm{mL}$ and IE = $103(20-300) \mathrm{CFU} / 100 \mathrm{~mL})($ Median and interquartile range) observed in household drinking waters was closely related to lack of awareness/knowledge of 'safe' handling/storage and inadequate hygiene practices and did not necessarily correspond to water quality at the source.

- Ceramic candle filters proved effective at removing FIO and their use should be promoted within such settings in order to further improve drinking water quality at the point-of- use.

- Finally, further reduction in diarrhoeal diseases among rural residents might best be achieved through adequate training of all stakeholders involved in the provision of 'safe' drinking water and the development of local programmes to raise awareness of the importance of good water, sanitation and hygiene practice. 


\section{Funding statements}

This research was made possible through the generous support of the Brazilian Science without Borders funding program (Ciências sem Fronteiras - BEX 11933/135). The authors are also grateful to Santander Universities who provided financial support during field work.

Acknowledgements: The authors gratefully acknowledge the support of professors Kepler França and Howard Pearson and colleagues from Federal University of Campina Grande (UFCG) for their cooperation and support.

\section{References}

ASA (Articulação Semiárido Brasileiro), n.d. Programa um milhão de cisternas para as famílias do semi-árido. http://www.asabrasil.org.br/ (accessed 20.05.16).

Bain, R.E.S., Wright, J.A., Christenson, E., Bartram, J.K., 2014. Rural: urban inequalities in post 2015 targets and indicators for drinking-water. Science of the Total Environment. 490, 509-513.

Bichai, F., Smeets, P.W., 2013. Using QMRA-based regulation as a water quality management tool in the water security challenge: experience from the Netherlands and Australia. Water Res. 47 (20), 7315-7326.

Briceno, B., Yusuf, A., 2012. Scaling up handwashing and rural sanitation: findings from a baseline survey in Tanzania. Water and Sanitation Program: Technical paper.

BSI (British Standards Institution), 2000a. Water quality: detection and enumeration of Escherichia coli and coliform bacteria - Part 1: membrane filtration method. London, UK.

BSI (British Standards Institution), 2000b. Water quality: detection and enumeration of intestinal enterococci - Part 2: membrane filtration method. London, UK.

BSI (British Standards Institution), 2001. Water quality: detection and enumeration of bacteriophages - Part 2: enumeration of somatic coliphages. London, UK.

Byappanahalli, M.N., Fujioka, R.S., 2004. Indigenous soil bacteria and low moisture may limit but allow faecal bacteria to multiply and become a minor population in tropical soils. Water Sci Technol. 50 (1), 27-32.

Byappanahalli, M.N., Roll, B.M., Fujioka, R.S., 2012. Evidence for occurrence, persistence, and growth potential of E. coli and Enterococci in Hawaii's soil environments. Microbes Environ. 27 (2), 164-170.

CDC (Center for Disease Control and Prevention), 2014. Safe water system: behavior change communications. Atlanta, USA.

Cirilo, J.A., 2008. Políticas publicas de recursos hídricos para o semiárido. Estudos Avançados. 22 (63), 61-82.

Curtis, V., Kanki, B., Cousens, S., Diallo, I., Kpozehouen, A., Sangare, M., Nikiema, M., 2001. Evidence of behaviour change following a hygiene promotion programme in Burkina Faso. Bull World Health Organ. 79 (6), 518- 27.

Curtis, V.A., Danquah, L.O., Aunger, R.V., 2009. Planned, motivated and habitual hygiene behaviour: an eleven countries review. Health Education Research. 24 (4), 655-673. 
de Wit, J.C., Broekhuizen, G., Kampelmacher, E.H., 1979. Cross- contamination during the preparation of frozen chickens in the kitchen. Journal of Hygiene. 83 (1), 27-32.

Desmarais, T.R., Solo-Gabriele, H.M., Palmer, C.J., 2002. Influence of soil on fecal indicator organisms in a tidally influenced subtropical environment. Appl Environ Microbiol. 68 (3), 1165-1172.

Djaouda, M., Gake, B., Menye, D.E., Togouet, S.H.Z., Nola, M., Njine, T., 2013. Survival and growth of Vibrio cholerae, Escherichia coli, and Salmonella spp. in well water used for drinking purposes in Garoua (North Cameroon). International Journal of Bacteriology. 2013, 1-7.

Dreibelbis, R., Freeman, M.C., Greene, L.E., Saboori, S., Rheingans, R., 2014. The impact of school water, sanitation, and hygiene interventions on the health of younger siblings of pupils: a cluster- randomized trial in Kenya. American Journal of Public Health. 104 (1), e91- e97.

Firth, J., Balraj, V., Muliyil, J., Roy, S., Rani, L.M., Chandresekhar, R., Kang, G., 2010. Point-of-use interventions to decrease contamination of drinking water: a randomized, controlled pilot study on efficacy, effectiveness, and acceptability of closed containers, moringa oleifera, and in-home chlorination in rural South India. The American Journal of Tropical Medicine and Hygiene. 82 (5), 759765.

Glass-Haller, L., 2010. Microbial and geochemical characterization of a contaminated freshwater ecosystem (the case of Vidy Bay, Lake Geneva, Switzerland). Doctorate, Université de Genève.

Gomes, U.A.F., Heller, L., Cairncross, S., Domenèch, L., Pena, J. L., 2014. Subsidizing the sustainability of rural water supply: the experience of the Brazilian rural rainwater-harvesting programme. Water International. 39 (5), 606-619.

Gopnik, A., Griffiths, T.L., Lucas, C.G., 2015. When younger learners can be better (or at least more open-minded) than older ones. Current Directions in Psychological Science. 24 (2), 87-92.

Guan, T.Y., Holley, R.A., 2003. Pathogen survival in swine manure environments and transmission of human enteric illness - A review. Journal of Environmental Quality, 32 (2), 383-392.

Günther, I., Fink, G., 2010. Water, sanitation and children's health: evidence from 172 DHS surveys. World Bank Policy Research Working Paper No. 5275. https://ssrn.com/abstract=1593423. (accessed 23.11.15).

Heikkila, T., Silva, F.O.E., Stellar, D., Filho, F.A.S., Tress, S., Lall, U., 2012. Designing sustainable and scalable rural water supply systems: evidence and lessons from Northeast Brazil. Columbia Water Centre and University of Ceara, Brazil.

Humphrey, T.J., Martin, K.W., Slader, J., Durham, K., 2001. Campylobacter spp. in the kitchen: spread and persistence. Journal of Applied Microbiology. 90, 115S120 S.

IBGE (Instituto Brasileiro de Geografia e Estatística), 2010. Censo demográfico 2010. http://www.sidra.ibge.gov.br (accessed 12.11.15). 
Jofre, J., Lucena, F., Blanch, R.A., Muniesa, M., 2016. Coliphages as model organisms in the characterization and management of water resources. Water. 8 (5), 1-21.

Jonczyk, E., Klak, M., Miedzybrodzki, R., Gorski, A, 2011. The influence of external factors on bacteriophages - review. Folia Microbiology. 56 (3), 191- 200.

Judah, T., Aunger, R., Schmidt, W., Granger, S., Curtis, V., 2009. Experimental pretesting of hand-washing interventions. American Journal of Public Health. 99 (S2), 405-411.

Kagan, L.J., Aiello, A.E., Larson, E., 2002. The role of the home environment in the transmission of infectious diseases. Journal of Community Health. 27 (4), 247267.

LEI_No_10638, 2003. Institui o Programa Permanente de Combate à Seca PROSECA. http://www.planalto.gov.br/ccivil_03/Leis/2003/L10.638.htm (accessed 18.08.15).

Liljestrand, H.M., 1985. Average rainwater $\mathrm{pH}$, concepts of atmospheric acidity, and buffering in open systems. Atmospheric Environment. 19 (3), 487-499.

Makutsa, P., Nzaku, K., Ogutu, P., Barasa, P., Ombeki, S., Mwaki, A., Quick, R. E., 2001. Challenges in implementing a point-of-use water quality intervention in rural Kenya. American Journal of Public Health. 91 (10), 1571- 1573.

MAPA (Ministério da Agricultura, Pecuária e Abastecimento), 2015. Informativo sobre a estiagem no Nordeste - no 84. Brasília, Brazil.

McLaughlin, L.A., Levy, K., Beck, N.K., Shin, G.A., Meschke, J.S., Eisenberg, J.N., 2009. An observational study on the effectiveness of point-of-use chlorination. Journal of environmental health. 71 (8), 48-53.

Mocé-Llivina, L., Lucena, F., Jofre, J., 2005. Enteroviruses and bacteriophages in bathing waters. Applied and Environmental Microbiology. 71 (11), 6838-6844.

Montgomery, M.A., Elimelech, M., 2007. Water and sanitation in developing countries: Including health in the equation. Environmental Science \& Technology, 41 (1), 17-24.

Moura, M.S.B., Galvincio, J.D., Brito, L.T.L., Souza, L.S.B., Sá, I.I.S., Silva, T. G. F., 2007. Clima e água de chuva no semi-árido. In: Brito, L.T.L., Moura, M.S.B., Gama, G.F.B. (eds.) Potencialidades da água de chuva no semi-arido brasileiro. Petrolina: Embrapa Semi-Árido. 35-39.

MS (Ministério da Saúde), 2011. Portaria no 2914, de 12 de Dezembro de 2011. Brasília, Brazil.

O'Reilly, C.E., Freeman, M.C., Ravani, M., Migele, J., Mwaki, A., Ayalo, M., Ombeki, S., Hoekstra, R.M., Quick, R., 2008. The impact of a school- based safe water and hygiene programme on knowledge and practices of students and their parents: Nyanza Province, western Kenya, 2006. Epidemiology and Infection. 136 (1), 80-91.

Perez-Vidal, A., Diaz-Gomez, J., Castellanos-Rozo, J. and Usaquen- Perilla, O.L., 2016. Long-term evaluation of the performance of four point- of-use water filters. Water Research. 98, 176-182.

Pinfold, J.V., 1990. Faecal contamination of water and fingertip-rinses as a method for evaluating the effect of low-cost water supply and sanitation activities on faeco-oral disease transmission. I. A case study in rural north-east Thailand. Epidemiol. Infect. 105, 363-375. 
PL_no_1, 2012. Portaria Interministerial no 1, de 25 de Julho de 2012. Ministério da Integração Nacional - Gabinete do Ministro, no 144 (Seção 1), p. 40. Brasília, Brazil.

Scott, E., Bloomfield, S.F., 1990. The survival and transfer of microbialcontamination via cloths, hands and utensils. Journal of Applied Bacteriology. 68 (3), 271-278.

Shields, K.F., Bain, R.E., Cronk, R., Wright, J.A., Bartram, J., 2015. Association of supply type with fecal contamination of source water and household stored drinking water in developing countries: a bivariate meta-analysis. Environ Health Perspective. 123,1222-1231.

Silva, R.M.A., 2006. Entre o combate à seca e a convivência com o semi-árido: transições paradigmáticas e sustentabilidade do desenvolvimento. PhD thesis, Universidade de Brasília. Brasília, Brazil. http://repositorio.unb.br/bitstream/ 10482/2309/1/2006_Roberto\%20Marinho\%20Alves\%20da\%20Silva.pdf (accessed 09.09.15).

UN (United Nations), 2015a. The millennium development goals report 2015. New York, US.

Waddington, H., Snilstveit, B., White, H., Fewtrell, L., 2009. Water, Sanitation and hygiene interventions to combat childhood diarrhoea in developing countries. The International Initiative for Impact Evaluation (3ie).

WHO/UNICEF (United Nations International Children's Emergency Fund / World Health Organization), 2015. Progress in drinking water and sanitation. Geneva, Switzerland.

WHO/UNICEF (United Nations International Children's Emergency Fund / World Health Organization), 2017. Safely managed drinking water - thematic report on drinking water 2017. Geneva, Switzerland.

Wright, J., Gundry, S., Conroy, R., 2004. Household drinking water in developing countries: a systematic review of microbiological contamination between source and point-of-use. Tropical Medicine \& International Health. 9 (1), 106-117.

Xavier, R.P., 2010. Influência de barreiras sanitárias na qualidade da água de chuva armazenada em cisternas no semiárido Paraibano. MPhill dissertation. Universidade Federal de Campina Grande. Paraíba, Brazil. http://www.hidro.ufcg.edu.br/cisternas/Dissertacao_Rogerio-Influencia\%20de\% 20 barreiras $\% 20$ sanitarias $\% 20$ na $\% 20$ qualidade $\% 20$ da $\% 20$ agua $\% 20$ de $\% 20$ chu va $\% 20$ armazenada $\% 20$ em $\% 20$ cisternas $\% 20$ no $\% 20$ semiarido\%20paraibano.p df (accessed 13.02.16). 
FIGURES
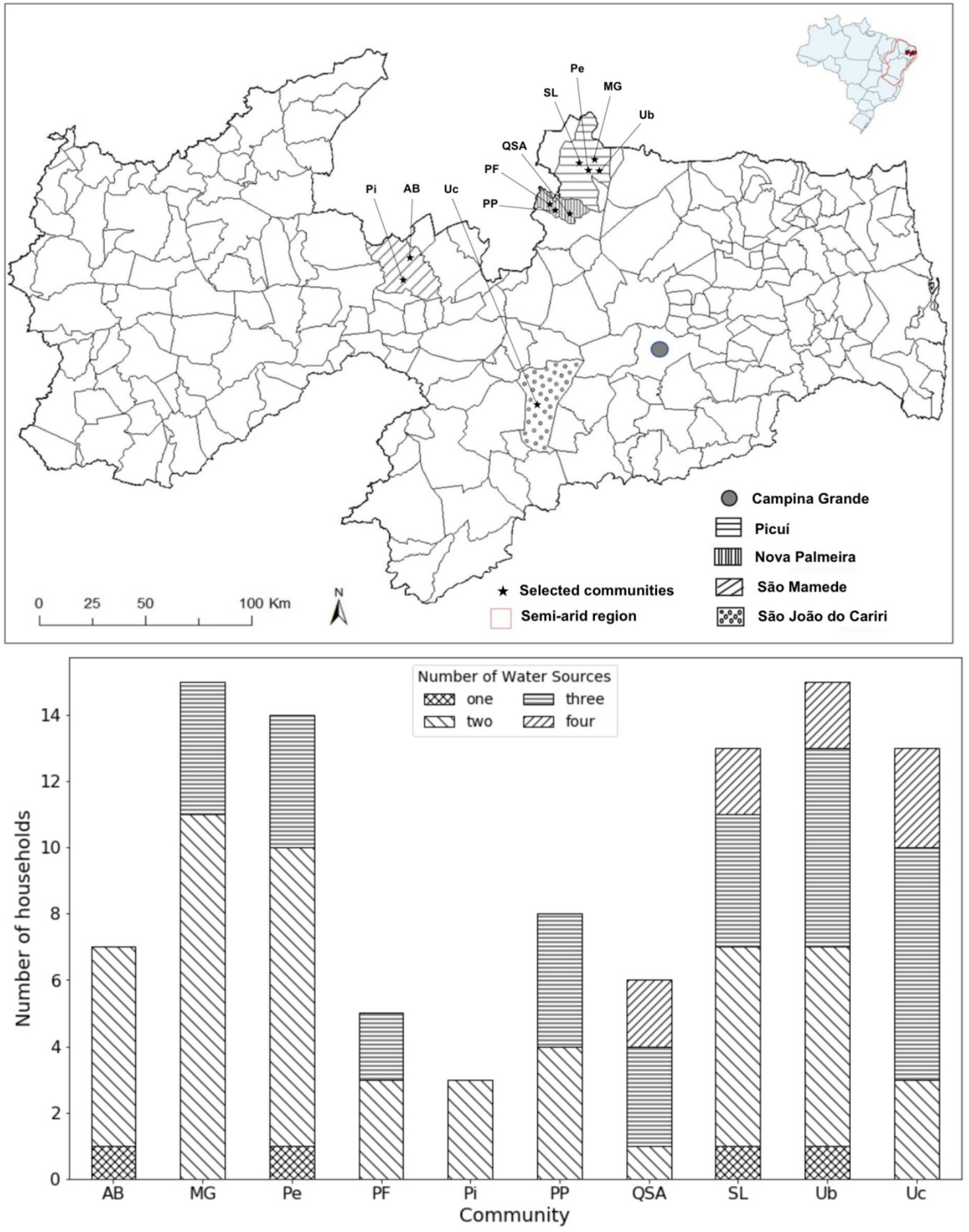

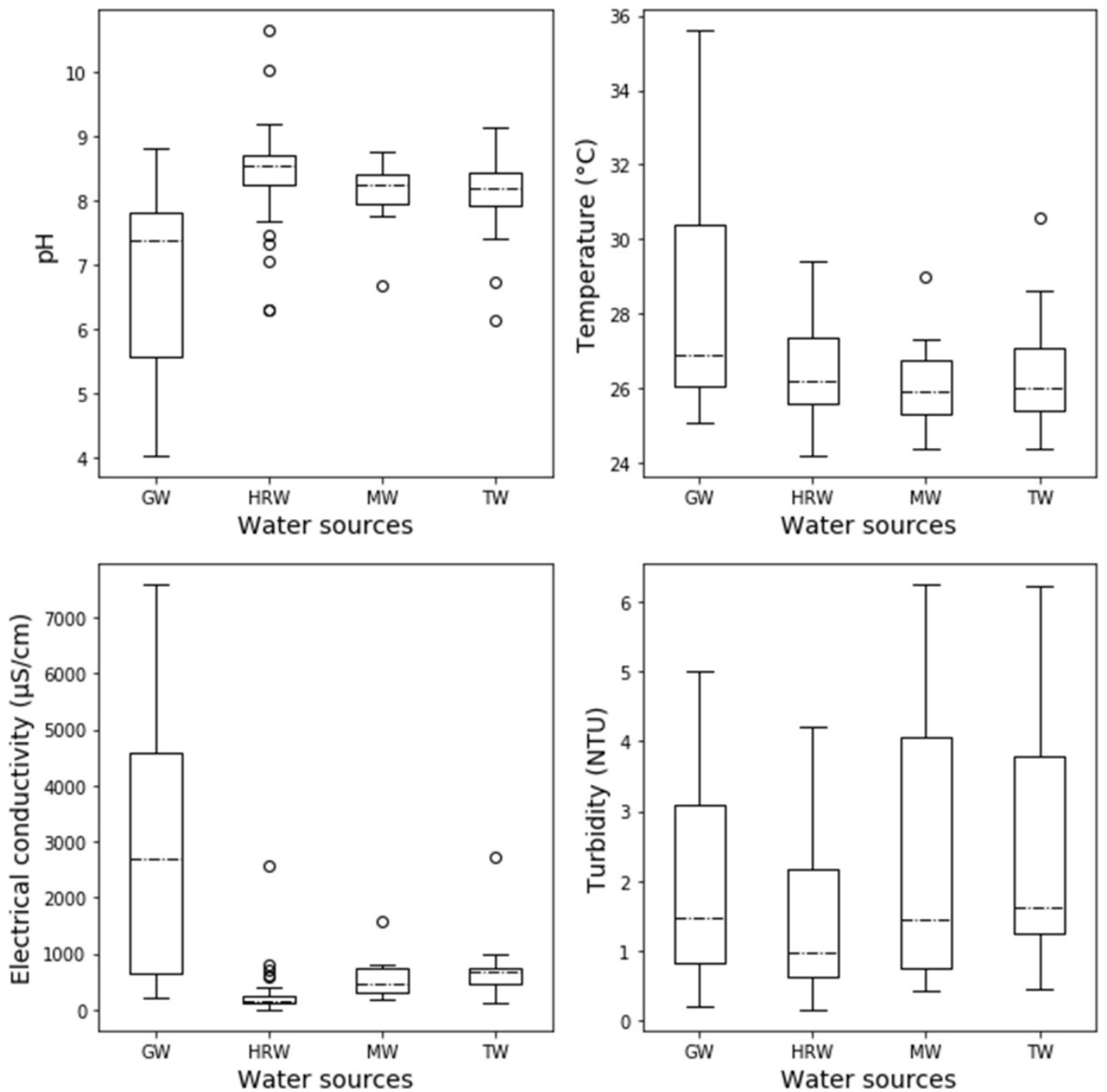

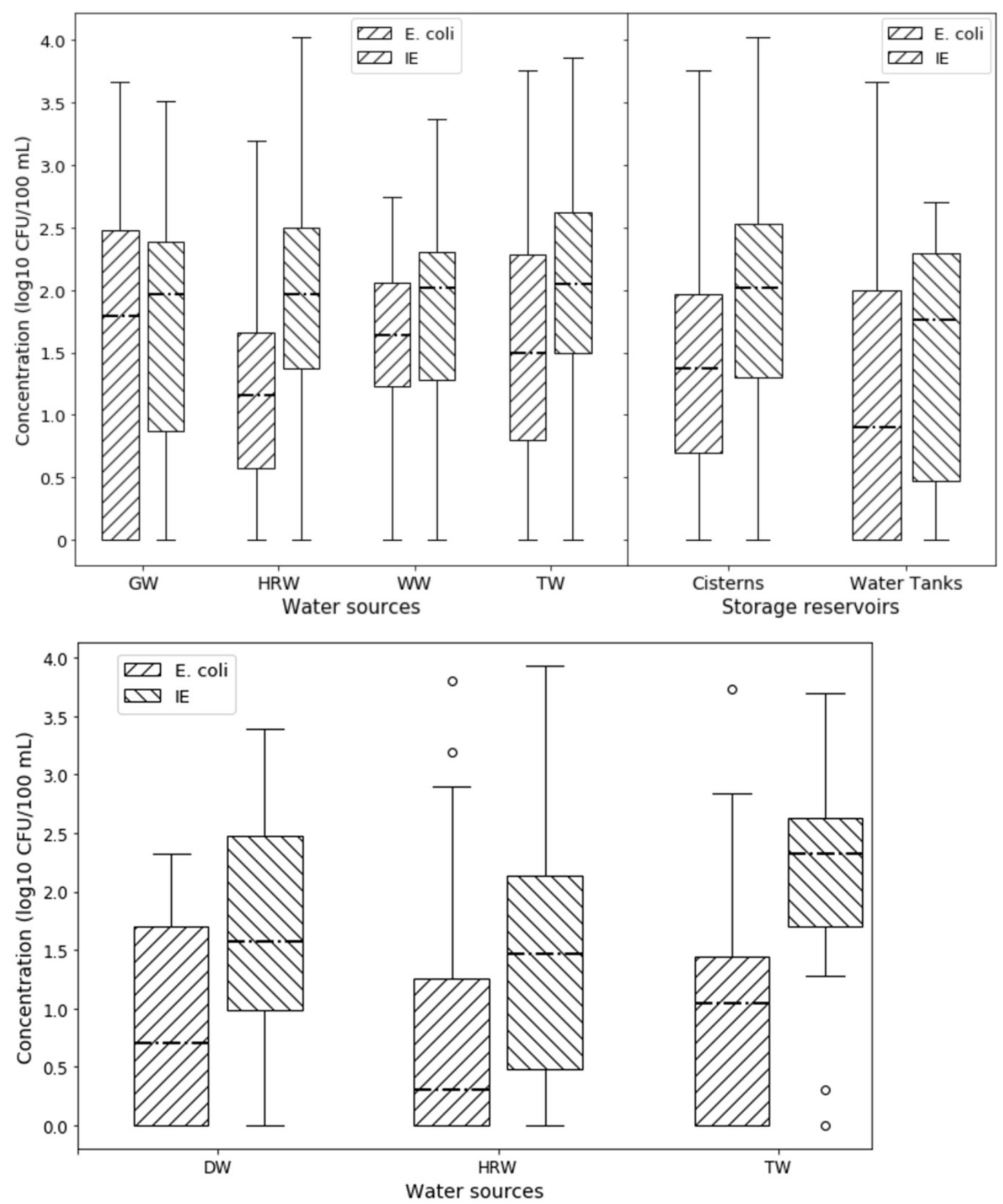

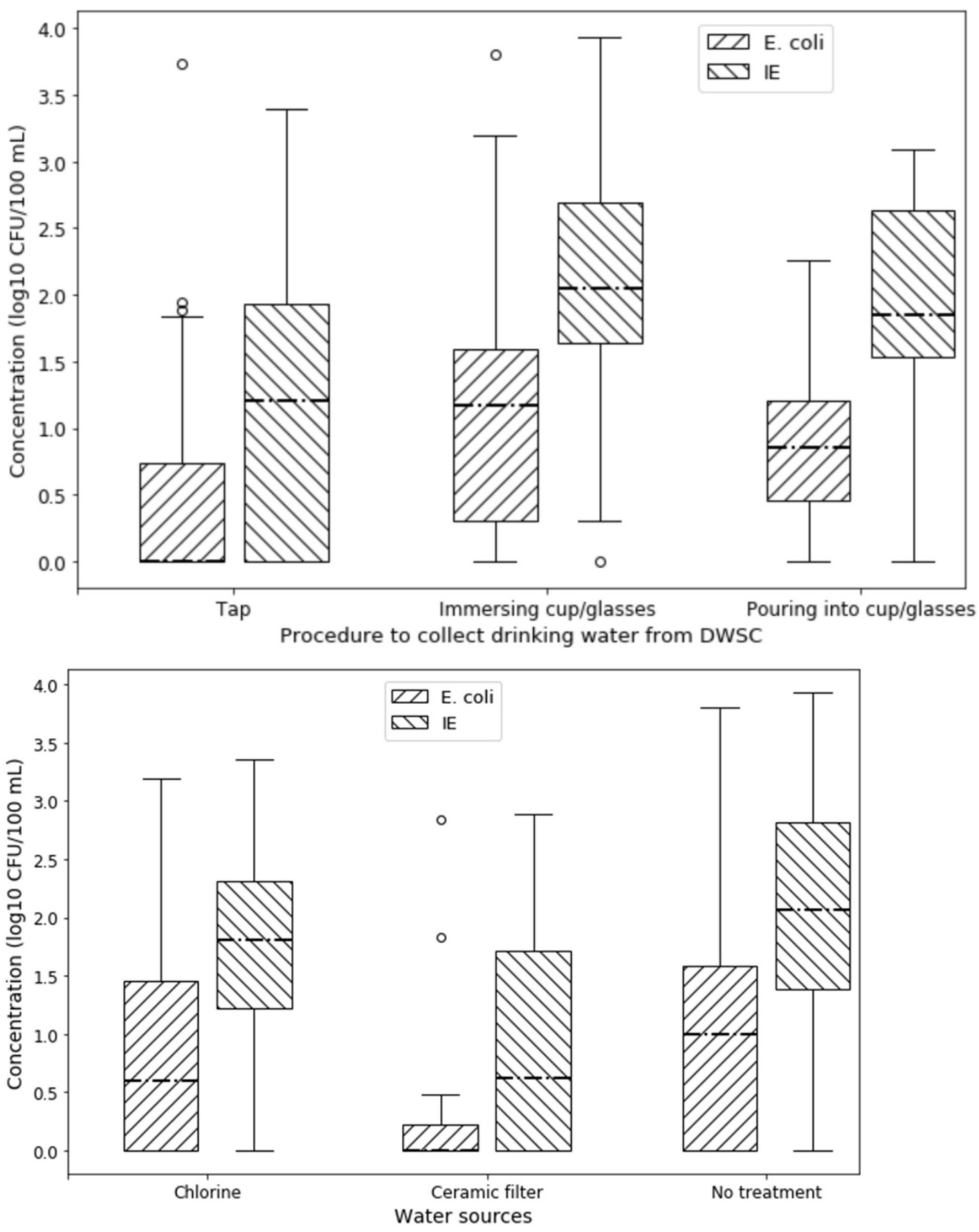

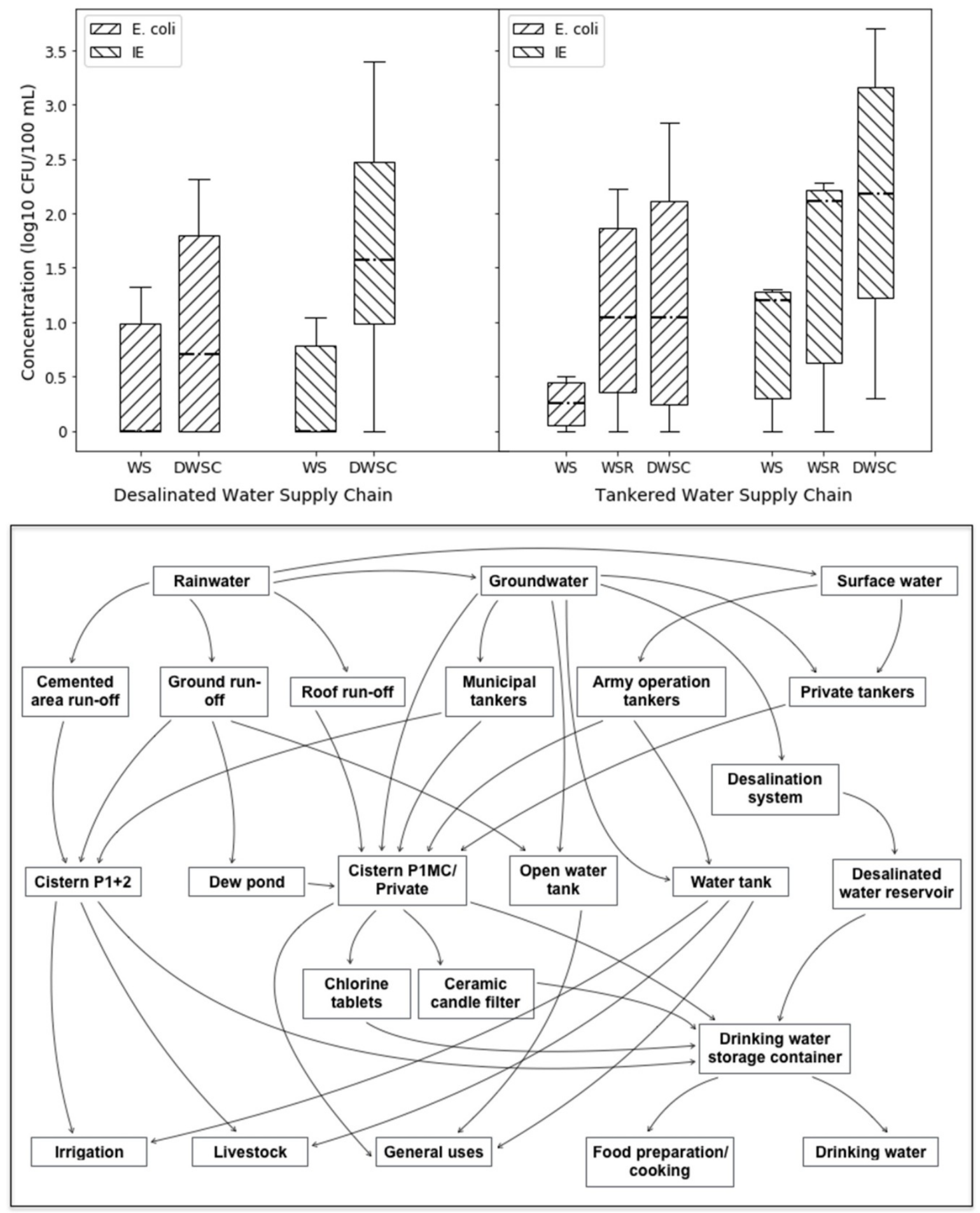


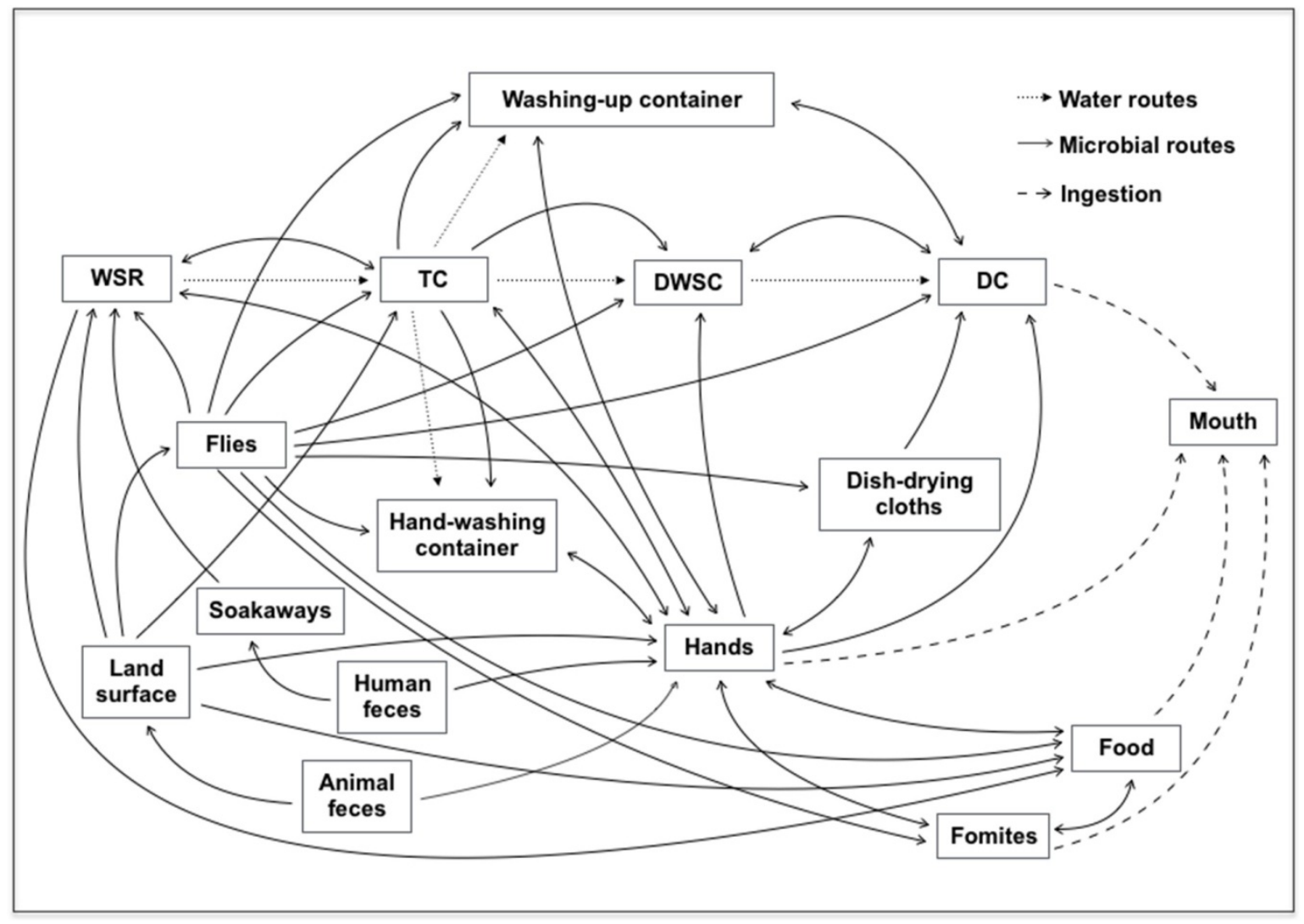


TABLES

\begin{tabular}{|c|c|c|c|c|c|}
\hline Municipalities & $\begin{array}{l}\text { Total } \\
\text { population }\end{array}$ & $\begin{array}{l}\text { Rural } \\
\text { population }\end{array}$ & $\begin{array}{l}\text { Selected rural } \\
\text { communities }\end{array}$ & $\begin{array}{l}\text { Number of } \\
\text { households }\end{array}$ & $\begin{array}{l}\text { Participant } \\
\text { households }\end{array}$ \\
\hline \multirow[t]{3}{*}{ Nova Palmeira } & 4849 & 1988 & PF & 70 & 5 \\
\hline & & & PP & 38 & 8 \\
\hline & & & QSA & 35 & 6 \\
\hline \multirow[t]{4}{*}{ Picuí } & 18704 & 6172 & MG & 76 & 15 \\
\hline & & & $\mathrm{Pe}$ & 57 & 14 \\
\hline & & & SL & 36 & 13 \\
\hline & & & $\mathrm{Ub}$ & 37 & 15 \\
\hline \multirow[t]{2}{*}{ São Mamede } & 7738 & 1780 & $A B$ & 17 & 7 \\
\hline & & & $\mathrm{Pi}$ & 10 & 3 \\
\hline São João do Cariri & 4309 & 1982 & Uc & 53 & 13 \\
\hline
\end{tabular}

\begin{tabular}{ccl}
\hline Community & Number of sources & Water sources \\
\hline $\mathrm{AB}$ & 2 & HRRW, CT \\
$\mathrm{MG}$ & 6 & DW, HRRW, HPT, CT, AOT, MGOT \\
$\mathrm{Pe}$ & 6 & HRRW, HCSRW, HPT, AOT, MGOT, HGSRW \\
$\mathrm{PF}$ & 6 & DW, HRRW, HPT, AOT, MGOT, DP \\
$\mathrm{Pi}$ & 2 & DW, CT \\
$\mathrm{PP}$ & 5 & HRRW, HCSRW, AOT, MGOT, DP \\
QSA & 5 & HRRW, HCSRW, MGOT, DP, HGSRW \\
$\mathrm{SL}$ & 7 & DW, HRRW, HPT, CT, AOT, MGOT, POT \\
$\mathrm{Ub}$ & 7 & HRRW, HCSRW, HPT, AOT, MGOT, POT, \\
$\mathrm{Uc}$ & & HGSRW \\
& 9 & HGSRW \\
\hline
\end{tabular}

\begin{tabular}{lcccc}
\hline Parameter & $\mathrm{n}$ & Minimum & Median $(\mathrm{IQR})$ & Maximum \\
\hline $\mathrm{pH}$ & 146 & 4.04 & $8.34(7.84-8.62)$ & 10.65 \\
Temperature $\left({ }^{\circ} \mathrm{C}\right)$ & 147 & 24.2 & $26.2(25.6-27.4)$ & 35.6 \\
Turbidity $(\mathrm{NTU})$ & 153 & 0.17 & $1.31(0.72-2.94)$ & 417 \\
Electrical conductivity & 133 & 9.0 & $346(143-723)$ & 7600 \\
$\left(\mu \mathrm{sS} \mathrm{cm}^{2}\right)$ & 153 & 1 & $22(4-108)$ & 5600 \\
E. coli $(\mathrm{CFU} / 100 \mathrm{~mL})$ & 153 & 1 & $103(20-300)$ & 10000 \\
$\mathrm{IE}(\mathrm{CFU} / 100 \mathrm{~mL})$ & & & & \\
\hline
\end{tabular}

\begin{tabular}{lcccc}
\hline Parameter & $\mathrm{n}$ & Minimum & Median $(\mathrm{IQR})$ & Maximum \\
\hline Turbidity $(\mathrm{NTU})$ & 88 & 0.17 & $0.72(0.39-1.28)$ & 33 \\
Free chlorine $(\mathrm{mg} / \mathrm{L})$ & 35 & 0 & $0(0-0)$ & 1.2 \\
E. coli $(\mathrm{CFU} / 100 \mathrm{~mL})$ & 88 & 1 & $3(1-26)$ & 6440 \\
$\mathrm{IE}(\mathrm{CFU} / 100 \mathrm{~mL})$ & 88 & 1 & $54(6-215)$ & 8640 \\
\hline
\end{tabular}

